\title{
Thermal history and oil charge on the UK Atlantic margin
}

\author{
J. Parnel1 ${ }^{1}$, P.F. Green ${ }^{2}$, G. Watt ${ }^{1}$ and D. Middleton ${ }^{1}$ \\ ${ }^{1}$ Geofluids Research Group, Department of Geology \& Petroleum Geology, University of Aberdeen, King's College, \\ Aberdeen AB24 3UE, UK \\ ${ }^{2}$ Geotrack International Pty Ltd, 37 Melville Road, Brunswick West, Victoria 3055, Australia
}

\begin{abstract}
Integrated apatite fission track analysis and vitrinite reflectance data show that well 204/19-1 in the West of Shetland region, UK Atlantic margin, has experienced only limited additional burial beyond present-day depths. Uplift and cooling to present-day levels probably occurred during late Cenozoic (Eocene to Miocene) basin inversion. Fluid inclusion data indicate that Paleocene-Eocene sandstones have experienced temperatures much higher than can be explained by burial alone. Temperatures up to $200 \pm{ }^{\circ} \mathrm{C}$ indicate the passage of hot fluid through Cenozoic sandstones, which by-passed the pre-Cenozoic section in this and other wells. The hot fluid event must have been of very brief duration (up to 100 years) to show no record in the fission track and reflectance data, implying that the fluids migrated through fracture systems.

Oil inclusions in the Cretaceous of well 204/19-1 have a chemistry that suggests derivation from a Kimmeridgian-aged source rock. They occur in cements that show no evidence for the hot fluid event and it is concluded that the cements pre-date the event. Oil inclusions in Cenozoic sandstones have a heavy, degraded character and were trapped at high temperature, suggesting that degradation was related to the hot fluid event. Present-day oils in the West of Shetland region are mixtures, which could reflect components from the two charges distinguished by the integrated thermal and geochemical histories. The inference of fracture-bound flow is consistent with existing models of overpressure development and hydrofracturing.
\end{abstract}

KEYWORDS: West of Shetland, Atlantic Margin, oil charge, fission track analysis, fluid inclusion analysis

\section{INTRODUCTION}

As hydrocarbon exploration continues on the European Atlantic margin, the pathways and timing of fluid migration in the region, including hydrocarbon migration, are important aspects of exploration models. Two aspects of hydrocarbon migration attract particular attention: the process by which hydrocarbons reach Paleocene sandstone reservoirs and the sequence of oil charge in a multiple charge history. Models for oil charge in the West of Shetland region include (1) temporary residence in Mesozoic reservoirs followed by remigration into the Paleocene ('motel' model of Lamers \& Carmichael 1999); (2) overpressure build-up in Cretaceous sandbodies followed by hydraulic fracturing and leakage into the Paleocene (Iliffe et al. 1999); and (3) direct migration into the Paleocene due to overpressure retardation of hydrocarbon generation (Carr \& Scotchman 2003). Evidence from organic geochemistry (Scotchman et al. 1998; Holmes et al. 1999; Goodchild et al. 1999), basin modelling (Jowitt et al. 1999) and fluid inclusion petrography (Parnell et al. 1998) indicates that more than one oil generation is present.

Using pilot studies on Jurassic sandstones from exploration wells, fluid inclusion analysis and apatite fission track analysis (AFTA $^{\mathbb{R}}$ ) were successfully integrated to help understand the history of fluid migration in the West of Shetland region (Parnell et al. 1999). However, investigation of the Cretaceous-Paleocene section is critical, as it is involved more directly in the migration and emplacement of oil in producing and prospective fields, including Foinaven, Schiehallion and Suilven (Ebdon et al. 1995; Grant et al. 1999; Jowitt et al. 1999) (Fig. 1). Accordingly, this study is based primarily on well 204/19-1, adjacent to the Foinaven Field. The extensive stratigraphic range of this well has made it the subject of detailed assessments of burial and thermal history (Green et al. 1999; Iliffe et al. 1999). Fluid inclusion temperature measurements from the Cretaceous-Paleocene section are interpreted within a thermal history framework constrained by apatite fission track analysis and vitrinite reflectance data throughout the well, to further understanding of thermal history in the region. Geochemical and thermal data from oil inclusions are used to integrate oil charge and thermal history and provide an insight into the charging mechanism and multiple charge history. The thermal history of samples in 204/19-1 has been assessed independently by Carr \& Scotchman (2003). The interpretations from the present study are incompatible with their conclusions, resulting in part from differing views regarding the influence of overpressure on the kinetics of palaeothermal indicators. 


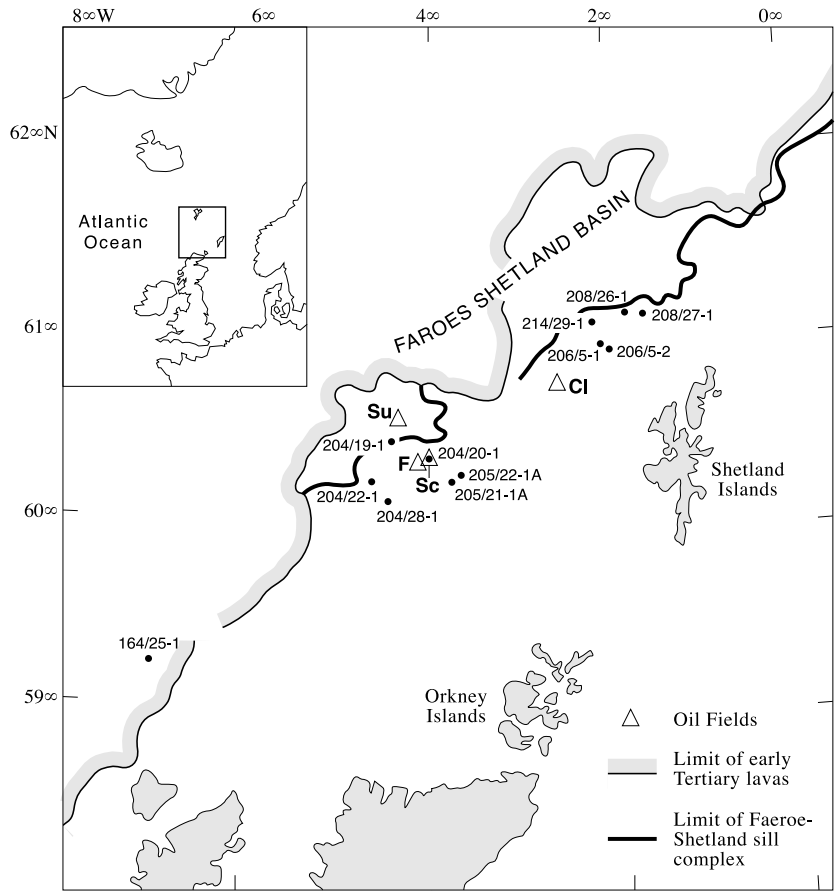

Fig. 1. Map of UK Atlantic margin, showing location of wells West of Shetland mentioned in text and oil fields (F, Foinaven; Cl, Clair; Sc, Schiehallion; Su, Suilven). Note close proximity of eastern limits of Tertiary extrusive and intrusive igneous rocks (adapted from Wycherley et al. 2003). Inset shows location within northeast Atlantic region.

\section{GEOLOGICAL SETTING}

The geology of the region of study has been discussed by numerous authors, including Ebdon et al. (1995) and Lamers \& Carmichael (1999). Most of the region is floored by half-graben rift sequences of Permo-Triassic continental clastic sediments deposited upon Devono-Carboniferous red beds or crystalline Caledonian basement. Jurassic-Cretaceous marine sedimentation was followed by a Cretaceous (Turonian) episode of inversion and erosion. Late Cretaceous rifting caused major normal faulting and deposition of thick marine shales. Further localized inversion along some of the faults occurred in the Early Paleocene, but generally deep-marine sedimentation persisted through the Paleocene, filling the basins with thick sandstone-shale sequences. Paleocene-Eocene volcanic activity was followed by thin paralic to continental sediments of Early Eocene age, in turn followed by thick Eocene-Oligocene marine clastic sedimentation. Several subsequent uplift events are recorded in the Cenozoic, after which a veneer of Pliocene and younger sediments formed the rocks currently on the seafloor. The source rocks for hydrocarbon discoveries are of Jurassic age and currently producing fields are in Paleocene sandstone reservoirs.

Well 204/19-1 (Fig. 1), close to the Foinaven Field, is critical to the understanding of stratigraphy in this region. This well contains rocks of Eocene, Paleocene, Upper Cretaceous, Lower Cretaceous, Jurassic, Permo-Triassic, and possibly also Devonian age. A fault probably separates the Permo-Triassic and younger sections in the well (Lamers \& Carmichael 1999). Cores through sandstones of Paleocene, Lower Cretaceous and Permo-Triassic age additionally allow sampling for diagenetic and palaeothermal studies. Along-strike to the northeast, well 214/29-1 also contains cored sandstones in both the Cretaceous and Paleocene sections, while well 206/5-2 contains core through sandstones of Cenozoic, Jurassic and Triassic age.
The fluid inclusion data from these three wells have been presented by Wycherley et al. (2003), while apatite fission track and vitrinite reflectance data are available primarily from the 204/19-1 well.

\section{THERMAL HISTORY RECONSTRUCTION IN WELL 204/19-1}

\section{Background and principles}

The basic principles involved in thermal history reconstruction using apatite fission track analysis and vitrinite reflectance data have been reviewed recently in detail (Green et al. 2004), with additional background information provided by Green et al. (2002). Fission track data in samples from a sedimentary section can provide direct estimates not only of the magnitude of maximum post-depositional palaeotemperatures through the section, but also the time at which the section cooled from that palaeothermal maximum. Integrating this information with vitrinite reflectance data through the section provides (1) corroborative evidence of the magnitude of any palaeothermal effects and (2) insight into the mechanism of heating and cooling, through the way in which palaeotemperatures vary through the section.

\section{Thermal history interpretation strategy}

A fundamental characteristic of both AFTA and vitrinite reflectance is that system response is dominated by maximum temperature: during heating, track lengths are reduced progressively and vitrinite reflectance increases progressively, such that no 'memory' of previous conditions is retained (Green et al. 2002). As a result, both techniques are subject to the fundamental limitation that they can provide no information on the approach to a palaeothermal maximum. For this reason, no attempt is made to constrain the whole thermal history of each sample. Instead, the approach focuses on those aspects of the thermal history that control the development of the apatite fission track analysis parameters; specifically the maximum palaeotemperature of each sample, the time at which cooling from that palaeotemperature began and (to some extent) the thermal history after the onset of cooling.

Extraction of thermal history solutions from AFTA data begins by assessing whether the fission track age and track length data in each sample can be explained if the sample had never been hotter than the present-day temperature at any time since deposition. If this is the case, then because fission track analysis parameters are dominated by maximum temperature, as with any thermal activated process, no further information is preserved on the post-depositional history. The burial history defined by the preserved section is combined with the presentday geothermal gradient to construct a 'default thermal history' for each sample. Using this history, AFTA parameters are modelled for each sample (Green et al. 1989, 2002). If the observed data show a greater degree of fission track annealing (i.e. track length and/or fission track age reduction) than expected on the basis of this default history, the sample must have been hotter in the past than it is at the present day.

In such cases, comparison of measured AFTA data with parameters predicted from a range of possible thermal history scenarios provides estimates of the magnitude of palaeotemperature and the time at which cooling began, with appropriate $95 \%$ confidence limits. Alternatively, if the data are consistent with the predictions of the default thermal history, a similar approach allows definition of an upper limit to the maximum palaeotemperature that the sample may have reached 
at any time after deposition. This proves to be the case with most of the samples discussed here.

Note that use of this 'default thermal history approach' is not equivalent to assuming that basal heat flow has not actually changed through time. Rather, use of a constant palaeogeothermal gradient is purely an analytical device, designed to assess whether the AFTA data (or VR data, as discussed below) contain any information on the palaeothermal history (i.e. have the samples been hotter in the past?). If so, the data can be interrogated to identify and characterize the major palaeothermal events that have affected the sedimentary section. This information can be integrated with the preserved stratigraphic section and thermal gradient to reconstruct a more complete thermal history for the sampled section.

Present-day temperatures in the well have been estimated using a thermal gradient of $34.1^{\circ} \mathrm{C} \mathrm{km}^{-1}$, derived from bottom-hole temperatures corrected using an empirical procedure adapted from the work of Andrews-Speed et al. (1984) and an assumed mean seabed temperature of $5^{\circ} \mathrm{C}$. Some corrected bottom-hole temperature values which appear to be anomalously low have been omitted in defining the final gradient value. The stratigraphy is summarized by Iliffe et al. (1999) and geological ages are attributed according to the time-scale of Harland et al. (1990). Since first returns were obtained from a depth of around $500 \mathrm{~m}$ below seabed, the stratigraphy of the shallowest part of the well is uncertain.

\section{Fission track data from well 204/19-1}

Fission track age and track length data in nine samples analysed from the 204/19-1 well are summarized in Tables 1 and 2 and plotted as a function of depth and present temperature in Figure 2, where the fission track age data are contrasted with the variation of stratigraphic age through the section. Fission tracks in almost all apatite grains from the two deepest samples, from units of Jurassic and Devonian age at present-day temperatures in excess of $125^{\circ} \mathrm{C}$, are totally annealed, and preserve no information on the palaeothermal history. Fission track ages in samples from the Tertiary section are consistently much older than the respective stratigraphic ages, at present-day temperatures between 30 and $80^{\circ} \mathrm{C}$. Values are generally around 200 to $300 \mathrm{Ma}$, and are similar to those measured today in the Scottish Highlands and adjacent basement regions (Thomson et al. 1999). These represent the most likely source areas for the sediments. This immediately shows that the apatite grains within this section have not undergone a severe degree of fission track annealing after deposition of the Cenozoic sediments, and suggests that any palaeothermal effects are likely to be only of moderate magnitude.

Thermal history solutions derived from the fission track data in each sample are summarized in Table 3. Note that these differ slightly from those presented by Green et al. 1999, as a transcription error resulted in erroneous stratigraphic data being used in that study.) In each sample from the Cenozoic section, the fission track data can be explained by a combination of the default thermal history and tracks formed prior to deposition, inherited from sediment source terrains, and do not require that the sample has been hotter than the respective present-day temperature at any time after deposition. In each case the fission track data allow definition of an upper limit to the magnitude of the maximum post-depositional palaeotemperature, as summarized in Table 3. These limits suggest that any palaeothermal effects in this well involved maximum temperatures only c. 10 to $30^{\circ} \mathrm{C}$ higher than present-day temperatures. Figure 3 illustrates the principles involved in extracting thermal history constraints from the fission track data, based on combined data from three samples from a core within the 204/19-1 well, of Late Paleocene age. Results from these three samples, closely spaced in depth, are very similar and can be treated as a single sample for the purposes of interpretation.

In the two deeper samples, the fission track data are dominated by the effects of the present-day thermal regime and preserve no information on the magnitude of any palaeothermal effects. These results provide support for the general magnitude of the present-day thermal gradient defined as explained earlier.

\section{Vitrinite reflectance data from well 204/19-1}

Vitrinite reflectance measurements provide supporting data for thermal history reconstruction. Data from samples from the 204/19-1 well are summarized in Table 3. All analyses were carried out using standard procedures (Cook 1982) involving measurement of maximum reflectance under oil, $R_{\mathrm{o}} \max$, with vitrinite identification being made on textural grounds, allowing an independent assessment to be made of the possible presence of reworked vitrinite populations from petrographic evidence, as well as allowing identification of caved material in subsurface samples. Alternation between reflectance and fluorescence modes allowed checking for associated fluorescing liptinite, bitumen impregnation, or the presence, intensity and source of oil-cut which may affect the reading. In most of the samples, 25 or more image fields were measured (Table 3), representing analyses of the highest quality, while data from samples in which lower numbers of fields were measured appear to be consistent with the overall trend.

Also shown in Table 3 are values of maximum palaeotemperature calculated from each measured vitrinite reflectance value using the Burnham \& Sweeney (1989) algorithm. As with the fission track data, a default thermal history is constructed for each vitrinite sample and, if the measured reflectance value is higher than the value predicted from the default thermal history, this suggests that the sample must have been hotter in the past. By adding a thermal event to the default thermal history, the value of maximum palaeotemperature which predicts the measured reflectance value can be determined.

Maximum palaeotemperatures derived from the reflectance data in this way are consistently greater than the present-day sample temperatures also shown in Table 3, suggesting that the sampled units have been slightly hotter in the past. Reconciliation of this observation with the fission track data in this well is discussed in the next section.

\section{Integration of fission track and vitrinite reflectance data, the palaeotemperature profile and mechanisms of heating and cooling}

In Figure 4, palaeotemperature constraints from fission track and vitrinite reflectance data in the 204/19-1 are plotted against depth. Constraints from the two techniques show a good level of consistency and the degree of heating suggested by the vitrinite reflectance data is within the amount allowed by the fission track data. The combined dataset defines a broadly linear palaeotemperature profile which is sub-parallel to the present-day profile (also shown in Fig. 4), suggesting a similar degree of heating in all sampled units. A small number of values based on vitrinite reflectance data within the Upper and Lower Cretaceous section are lower than the general trend of the main dataset, probably due to geochemical suppression (Carr 2000) of reflectance values in these samples. Setting these data aside, on the basis of the main body of the data from the well it is 


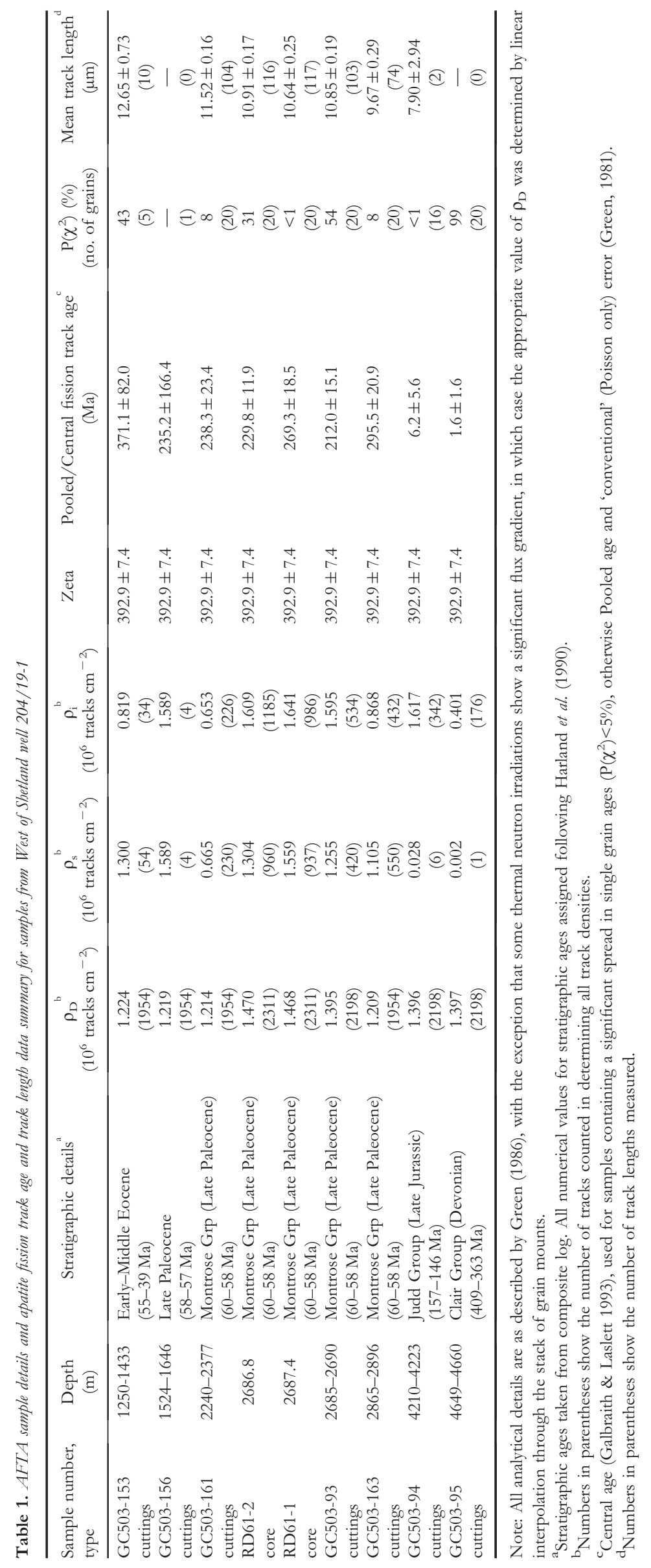


Table 2. Track length data for samples from well 204/19-1

\begin{tabular}{|c|c|c|c|c|c|c|c|c|c|c|c|c|c|c|c|c|c|c|c|c|c|c|c|}
\hline ample & Mean & & er & & & & & & & & mbe & of $t$ & $\mathrm{ac}$ & n le & igth & iter & & & & & & & \\
\hline number & $(\mu \mathrm{m})$ & $u m)$ & of tracks & 1 & 2 & 3 & 4 & 5 & 6 & 7 & 8 & 9 & 10 & 11 & 12 & 13 & 14 & 15 & 16 & 17 & 18 & 19 & 20 \\
\hline GC503 & $12.65 \pm$ & 2.31 & 10 & - & - & - & - & - & - & - & 1 & - & - & 1 & 1 & 1 & 3 & 3 & - & - & - & - & - \\
\hline GC503-161 & $11.52 \pm 0.16$ & 1.68 & 104 & - & - & - & 1 & - & - & - & 1 & 1 & 13 & 17 & 31 & 27 & 8 & 4 & - & - & - & - & - \\
\hline 2D61-2 & $10.91 \pm 0.17$ & 1.86 & 116 & - & - & - & - & 3 & - & 1 & 4 & 4 & 16 & 22 & 34 & 20 & 10 & 2 & - & - & - & - & - \\
\hline RD61-1 & $10.64=$ & 2.70 & 117 & - & - & 1 & 3 & 2 & 3 & 4 & 4 & 4 & 11 & 20 & 36 & 15 & 7 & 4 & - & 1 & 1 & 1 & - \\
\hline GC503-9 & $10.85 \pm 0.19$ & 1.95 & 103 & - & - & - & - & 1 & 1 & 4 & 2 & 4 & 14 & 23 & 28 & 16 & 8 & 1 & - & - & 1 & - & - \\
\hline GC503-94 & $7.90 \pm 2.94$ & 4.15 & 2 & - & - & - & - & 1 & - & - & - & - & - & 1 & - & - & - & - & - & - & - & - & - \\
\hline GC503-95 & no confined tracks & - & - & - & - & - & - & - & - & - & - & - & - & - & - & - & - & - & - & - & - & - & - \\
\hline
\end{tabular}

${ }^{\mathrm{a}}$ Interval $n$ refers to number of tracks with lengths between $n-1 \mu \mathrm{m}$ and $n \mu \mathrm{m}$.

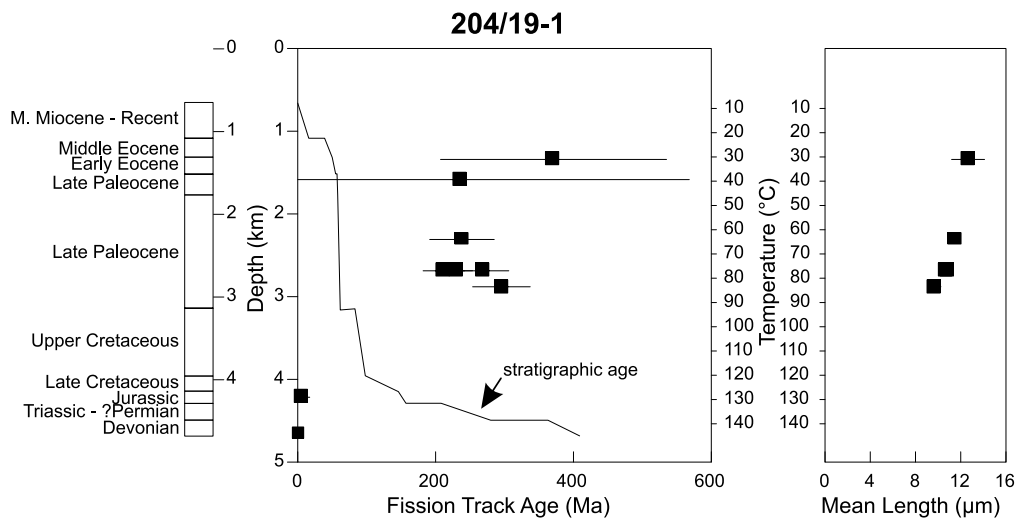

Fig. 2. Apatite fission track analysis parameters plotted against sample depth and present temperature for samples from the 204/19-1 well. The variation of stratigraphic age with depth is also shown, as the solid line in the central panel. Present-day temperatures shown here are derived from corrected bottom-hole temperature (BHT) data as explained in the text. concluded that units of Middle Eocene through Devonian age have been hotter in the past.

The fission track data provide no independent information on the timing from cooling. This is due largely to the relatively small degree of heating, as confirmed by the vitrinite reflectance data, coupled with the disposition of the available samples. Samples which reached palaeotemperatures in excess of $110^{\circ} \mathrm{C}$ prior to cooling should provide good estimates of the time of cooling. However, due to the lack of sandstones within the Upper Cretaceous section, no apatite samples are available from the appropriate part of the section. Therefore indirect methods are used to estimate the timing of cooling from the palaeotemperatures defined by the reflectance data.

The linearity of the palaeotemperature profile in Figure 4 suggests that the most likely mechanisms of heating and cooling were burial and subsequent exhumation. The consistent offset of results from units of Middle Eocene age and older shows that heating and cooling began after deposition of that unit. Thus, an explanation of the observed heating in terms of deeper burial and subsequent exhumation during the interval represented by the Middle Eocene to Middle Miocene unconformity seems most likely, presumably related to Late Cenozoic basin inversion.

Note also that the palaeotemperature constraints quoted in Table 3 refer to assumed heating and cooling rates of $1{ }^{\circ} \mathrm{C} \mathrm{Ma}^{-1}$ and $10^{\circ} \mathrm{C} \mathrm{Ma}^{-1}$, respectively. These rates appear reasonable for heating related to deeper burial prior to Late Cenozoic inversion (with the final reconstruction requiring around $30^{\circ} \mathrm{C}$ of heating between deposition of the youngest preserved Eocene sediments, at around $40 \mathrm{Ma}$, and the onset of inversion at perhaps $20 \mathrm{Ma}$ ). However, they are much slower than would be appropriate for heating due to hot fluid circulation (see later discussion). The kinetics of fission track annealing are such that changing the assumed heating rate by an order of magnitude is equivalent to a change of $c .10^{\circ} \mathrm{C}$ in the required maximum palaeotemperature (Green et al. 1989) with higher heating rates requiring higher temperatures and vice versa. Since the kinetics of vitrinite reflectance are similar to those of apatite fission track analysis (Duddy et al. 1994), a similar conclusion applies to palaeotemperatures derived from vitrinite reflectance data.

\section{Palaeogeothermal gradients and removed section}

Assuming that heating was due, at least in part, to deeper burial, determining the range of palaeogeothermal gradients that are consistent with the palaeotemperatures as a function of depth, and extrapolating the fitted profiles to an assumed palaeosurface temperature allows estimation of the amount of missing section. These two parameters are highly correlated, such that higher palaeogeothermal gradients require correspondingly lower values of removed section, and vice versa. Statistical techniques (based on likelihood theory due to the ranges of palaeotemperature allowed by the fission track data) allow definition of the range of each parameter allowed by the palaeotemperature constraints within 95\% confidence limits (Bray et al. 1992).

This analysis depends critically on several assumptions, as discussed by Bray et al. (1992) and in more detail by Green et al. (2002). However, as discussed by Green et al. (1995) and Crowhurst et al. (2002), this approach gives results in wellconstrained situations which are highly consistent with independent geological constraints and, overall, the approach is regarded as valid, at least to a first approximation. Since the purpose of the analysis here is simply to provide a framework for predicting thermal histories within the preserved section, the results can be used with confidence.

Figure 5 shows the range of values of palaeogeothermal gradient and removed section which is consistent with the palaeotemperature constraints in the 204/19-1 well. While the 
Table 3. Thermal history interpretation summary of AFTA and VR data in samples from West of Shetland well 204/19-1

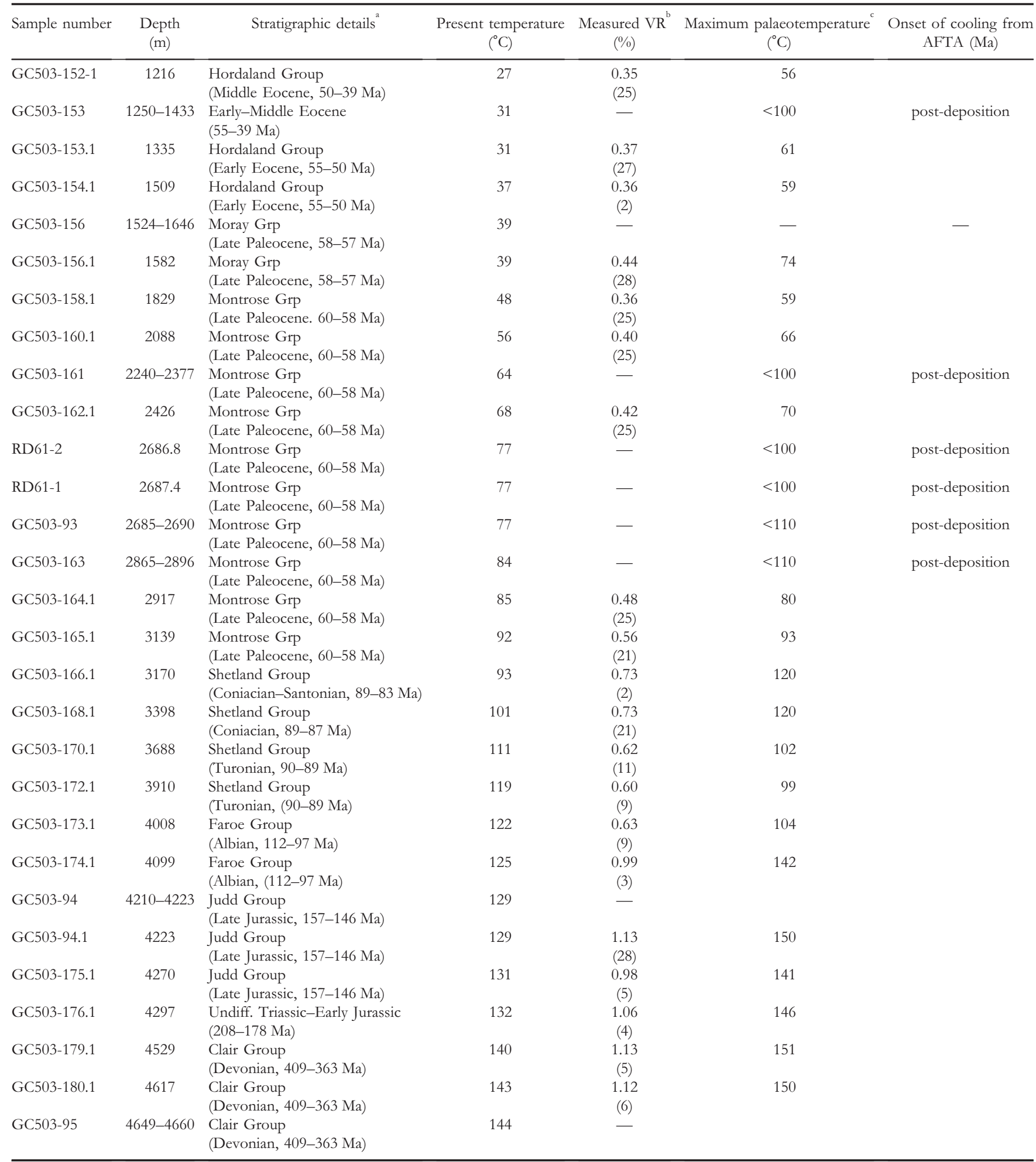

${ }^{a}$ All numerical values for stratigraphic ages assigned following Harland et al. (1990).

${ }^{\mathrm{b}}$ Numbers in parentheses show the number of fields measured.

${ }^{\mathrm{C}_{1}}$ Thermal history interpretation has been carried out using methods outlined by Green et al. (2004), using heating and cooling rates of $1^{\circ} \mathrm{C} \mathrm{Ma}{ }^{-1}$ and $10^{\circ} \mathrm{C} \mathrm{Ma}{ }^{-1}$, respectively.

best-fit palaeogeothermal gradient is close to $30^{\circ} \mathrm{C} \mathrm{km}^{-1}$, values between c. 25 and $c .36^{\circ} \mathrm{C} \mathrm{km}^{-1}$ are allowed within $95 \%$ confidence limits. The present-day thermal gradient of $34.1^{\circ} \mathrm{C} \mathrm{km}^{-1}$ lies within the range of allowed gradients and, therefore, an explanation of the observed palaeothermal effects solely in terms of deeper burial, with no change in basal heat flow, provides an adequate description of the data. On this basis, Figure 5 shows that between $630 \mathrm{~m}$ and $900 \mathrm{~m}$ of additional burial and subsequent exhumation is required to explain the observed palaeotemperatures. This is consistent 

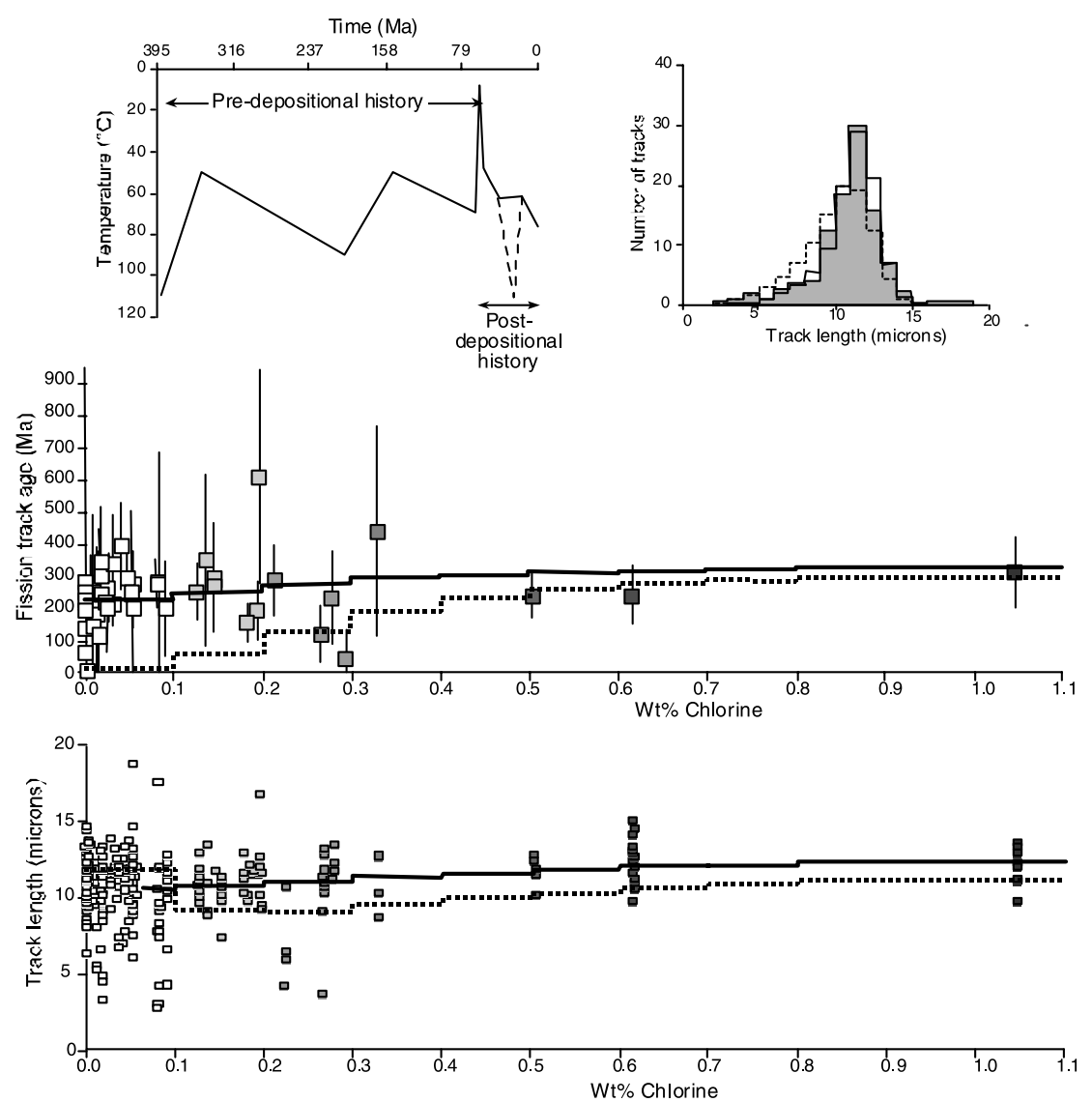

Fig. 3. Apatite fission track data in a composite sample from Late Paleocene sandstones at depths between $2685 \mathrm{~m}$ and $2690 \mathrm{~m}$ in the 204/19-1 well, together with predictions from two thermal history scenarios illustrated at top left. The thermal history, shown by a solid line, represents a combination of the 'default thermal history', as defined in the text, plus a hypothetical pre-depositional history. The measured distribution of confined track lengths (shaded, top right) shows a good match to the length distribution predicted from this history (solid line, top right). The variation of measured fission track age vs. chlorine content in individual apatite grains (centre) and track length with chlorine (lower) also shows a good match to the predictions of this history. In contrast, a history involving heating to $110^{\circ} \mathrm{C}$ at $20 \mathrm{Ma}$, as shown by the dashed line at top left, gives predictions (also shown by dashed lines in the other plots) that show a very poor match to the measured data and can be ruled out. By similar reasoning, the fission track data show that this sample cannot have been heated to $>100^{\circ} \mathrm{C}$ at any time since deposition. with the reconstructed burial history for this well shown by Iliffe et al. (1999), with around $650 \mathrm{~m}$ of section deposited and removed on the Late Cenozoic unconformity in this well.

The above analysis assumes a surface temperature during the Miocene palaeothermal maximum of $10^{\circ} \mathrm{C}$, but values appropriate to other preferred values of surface temperature can be calculated easily by adding or subtracting the depth increment corresponding to the decrease or increase in surface temperature, for the appropriate value of palaeogeothermal gradient. For example, if the palaeogeothermal gradient was $40^{\circ} \mathrm{C} \mathrm{km}^{-1}$ and the palaeosurface temperature was $10^{\circ} \mathrm{C}$ higher than the value assumed in the calculation, the estimated eroded section should be reduced by $250 \mathrm{~m}$. Different heating rates can be allowed for in a similar fashion, with an order of magnitude change in heating rate equivalent to a $10^{\circ} \mathrm{C}$ change in palaeotemperature (palaeotemperatures increase for higher heating rates and decrease for lower heating rates). For typical values, the assumed value of heating rate will not affect the shape or slope of the palaeotemperature profile significantly.

\section{Thermal history reconstruction}

Based on the assumption that the palaeogeothermal gradient has not changed since the Late Cenozoic palaeothermal maximum, which seems acceptable given the lack of reason to invoke any changes in basal heat flow, thermal histories for the units intersected in the 204/19-1 well can be reconstructed by combining the appropriate default thermal histories with the effects of deeper burial by $765 \mathrm{~m}$ of sediment on the Middle Eocene to Middle Miocene unconformity (if the palaeosurface temperature was higher than the assumed value of $10^{\circ} \mathrm{C}$, this amount would be reduced accordingly and readily attributable to erosion by bottom currents). Figure 6 illustrates the resulting thermal history reconstruction, in which the magnitude of the dominant phase of maximum palaeotemperatures in the Late Cenozoic is constrained well by the fission track and vitrinite reflectance data from this well. The AFTA and VR data provide a consistent framework within which the fluid inclusion results from Cenozoic and Cretaceous sandstones can be understood. This forms the basis of the remainder of this paper.

Following previous comments, note that the postdepositional thermal history of sediments intersected in this well prior to the onset of cooling is not constrained by the AFTA and vitrinite reflectance data, which are dominated by the maximum temperature episode. Thus, possible lower temperature peaks in the earlier history due, for example, to deeper burial on earlier unconformities and episodes of elevated palaeoheat flow, are not included in Figure 6.

Carr \& Scotchman (2003) recently published an alternative style of thermal history for the 204/19-1 well, based in part on the suggestion that vitrinite reflectance values are retarded by overpressuring in the Mesozoic section. The model developed by Carr \& Scotchman (2003) includes significantly elevated heat flow during Cretaceous to Early Cenozoic times, but the AFTA data presented here clearly show that the influence of any elevation in heat flow during these times was sufficiently minor that no evidence is preserved in the data (i.e. palaeotemperatures achieved by sampled horizons during any episodes of elevated palaeoheat flow were lower than the respective present-day temperatures). Thus, the conclusions developed based on comparison of maximum palaeotemperatures from AFTA and fluid homogenization temperatures are reliable and remain unaffected by any assumptions regarding heat flow variation through time. 
Temperature $(\infty \mathrm{C})$

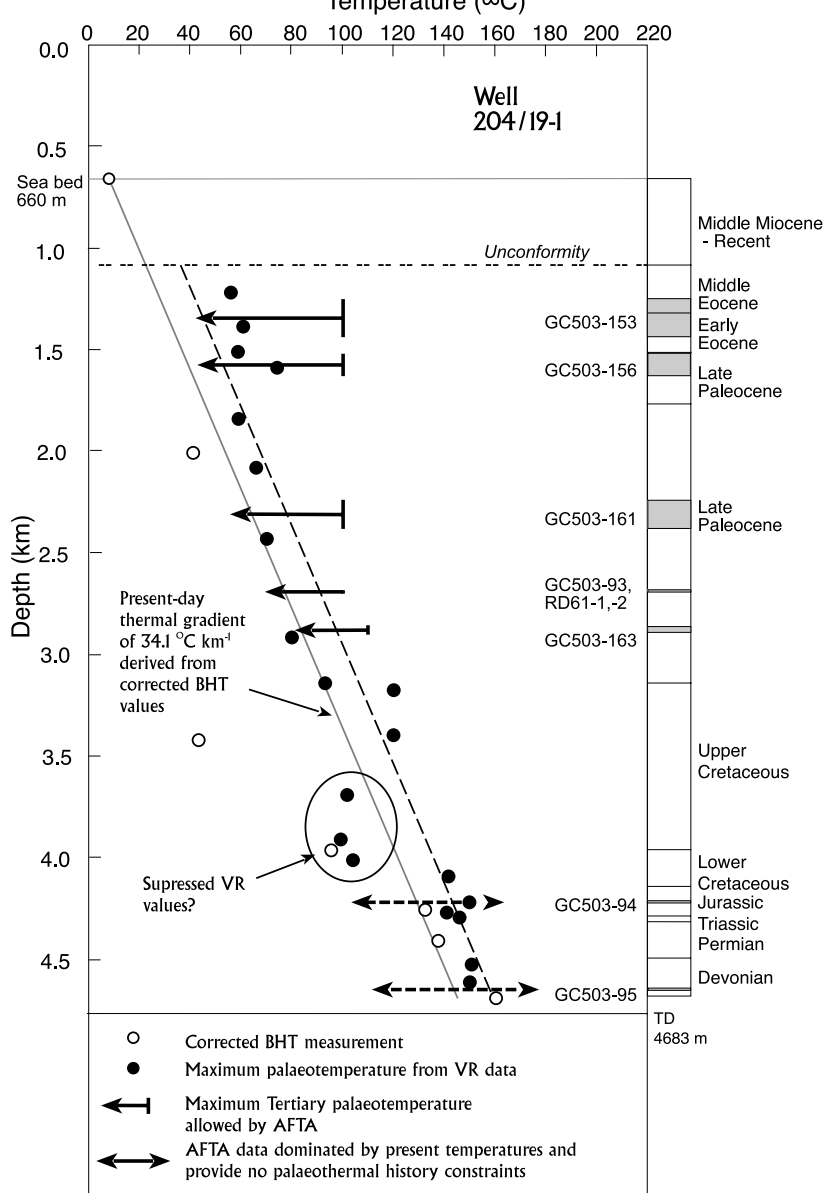

Fig. 4. Palaeotemperature constraints derived from fission track and vitrinite reflectance data in the 204/19-1 well, plotted against depth (measured depth, md). Most of the palaeotemperatures from the reflectance data plot slightly above the present-day temperature profile, defining a generally linear profile suggesting that the preMiocene section has been hotter in the past, with deeper burial providing the most likely explanation of the heating. A small number of reflectance data from the Cretaceous section plot below the overall trend, probably due to geochemical suppression of reflectance levels in the sampled units. Palaeotemperature constraints from apatite fission track analysis, while not definitely requiring any palaeo-heating, are consistent with those from vitrinite reflectance. Miocene-Eocene unconformity after Iliffe et al. (1999).

\section{FLUID INCLUSION MEASUREMENTS}

\section{Methodology}

Samples of core or cuttings were prepared as doublypolished wafers and examined using a Linkam THM600 heating-freezing stage attached to an Olympus BH-2 petrographic microscope. Microthermometry to measure homogenization temperatures was undertaken using standard procedures (Shepherd et al. 1985). Fluorescence under ultraviolet light was determined using a Nikon Eclipse 600 microscope with a UV-2A filter block. Measurement of the API ${ }^{\circ}$ gravity of inclusion oils was made using a patented in-house method at Fluid Inclusion Technologies Inc., based upon optical behaviour during cooling.

Gas chromatography of inclusion oils was undertaken by Torkelsen Geochemistry Inc. using a proprietary technique in which inclusion oils are liberated by mechanical crushing after careful removal of hydrocarbons on grain surfaces. The oils are analysed by a combined solvent and thermal extraction procedure.
204/19-1

(palaeosurface temperature $=10^{\circ} \mathrm{C}$ )

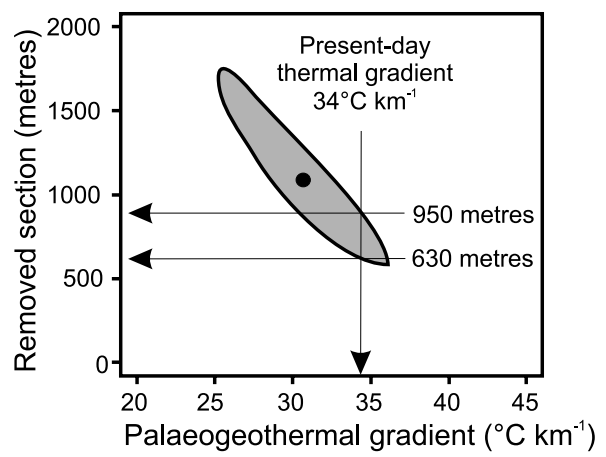

Fig. 5. Fitting a linear profile to the palaeotemperature constraints from apatite fission track analysis and vitrinite reflectance data shown in Figure 4 allows definition of the values of palaeogeothermal gradient which are consistent with the data. Extrapolation of the fitted profiles to an assumed palaeosurface temperature allows estimation of the amount of additional section required to explain the observed palaeotemperatures (and subsequently removed by erosion). Allowed values of palaeo-gradient and removed section are correlated highly, such that higher gradients require lower amounts of removed section and vice versa. The shaded region shows the range of values of each parameter allowed by the palaeotemperature constraints in well 204/19-1. Palaeo-gradients much higher than the present-day gradient of $34.1^{\circ} \mathrm{C} \mathrm{km}^{-1}$ are not allowed. If the palaeogradient was equal to the present-day value, results from this well suggest between $630 \mathrm{~m}$ and $950 \mathrm{~m}$ of additional section were deposited and subsequently removed on the Eocene-Miocene unconformity in this well.

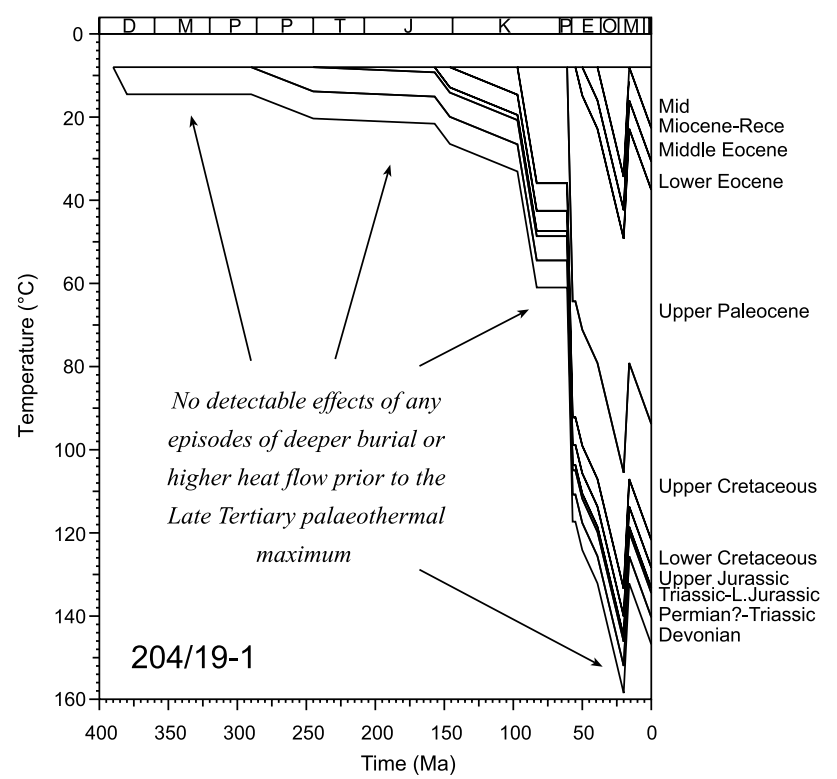

Fig. 6. Combination of the additional section required by the palaeotemperature results in this well with the default thermal history provides a final thermal history reconstruction for the 204/19-1 well. Note that this reconstruction does not include factors such as variation in palaeosurface temperature, or deeper burial on preEocene unconformities, as the history is assumed to be dominated by the effects of deeper burial prior to Late Tertiary exhumation. In addition, no changes in heat flow have been included, as the data show that the palaeogeothermal gradient at the palaeothermal maximum was close to the present-day value.

\section{Results}

Fluid inclusion homogenization temperature data, previously reported by Wycherley et al. (2003), were recorded from 12 


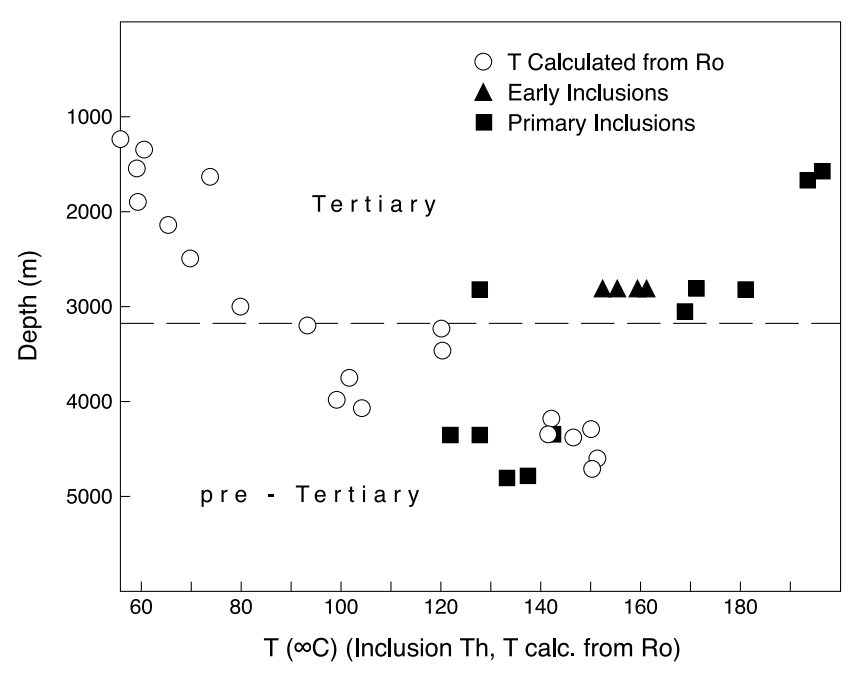

Fig. 7. Mean homogenization temperatures $\left(T_{\mathrm{h}}\right)$ from fluid inclusion populations in sandstones and temperatures $\left(T_{\text {calc }}\right)$ derived from vitrinite reflectance data using the algorithm of Burnham \& Sweeney (1989) in well 204/19-1. Reflectance-derived temperatures show an expected increase with depth, but highest fluid inclusion temperatures are at shallowest levels.

samples in well 204/19-1, in quartz cements and/or healed microfractures through quartz grains which can be shown, petrographically, to post-date deposition of the sandstone. In many samples, more than one population of inclusions can be distinguished. These include inclusions at the grain-overgrowth boundary, or within the overgrowth, which are demonstrably primary (entrapped during cement deposition), and inclusions in trails which pre-date the cement (early secondary) or crosscut and, therefore, post-date the cement (late secondary). Both aqueous and oil inclusions occur. Mean values of homogenization temperature for primary and early secondary populations of aqueous inclusions are plotted against sample depth in Figure 7. The same plot also shows maximum palaeotemperatures (listed in Table 3) calculated from the vitrinite reflectance data using the algorithm presented by Burnham \& Sweeney (1989).

While the fluid inclusion temperatures are consistent with the reflectance-derived temperatures in the pre-Cenozoic section, in the Paleocene-Eocene they exhibit higher values increasing progressively upwards to the shallowest sample in the Eocene. At some levels a range of values is found, but they include anomalously high temperatures. Consequently, there is an increasing discrepancy between the two estimates of palaeotemperature upward through the Paleocene-Eocene, which at the top of this section exceeds $100{ }^{\circ} \mathrm{C}$.

Figure 8 shows an example of the total dataset for a sample in the Paleocene section. There are several populations of inclusions; aqueous inclusions in quartz cement are very hot and they are moderately hot in trails. Oil inclusions show more variable temperatures, but these partly reflect oil composition, which is variable judging by a range of colours in normal light (yellow to dark brown) and a range of fluorescence under ultraviolet light (yellow to blue) and so it is unwise to compare them in detail. However, it is notable that oil inclusions exhibit higher homogenization temperatures than are encountered normally in sedimentary basins (e.g. Walderhaug 1994). The presence of hydrocarbon fluids suggests that a pressure correction to the aqueous inclusion homogenization temperatures is not necessary (Pratt \& Burruss 1988). Semi-quantitative measurements of API gravity for the oil inclusions show that the Cretaceous-hosted inclusions contain light oils in the range

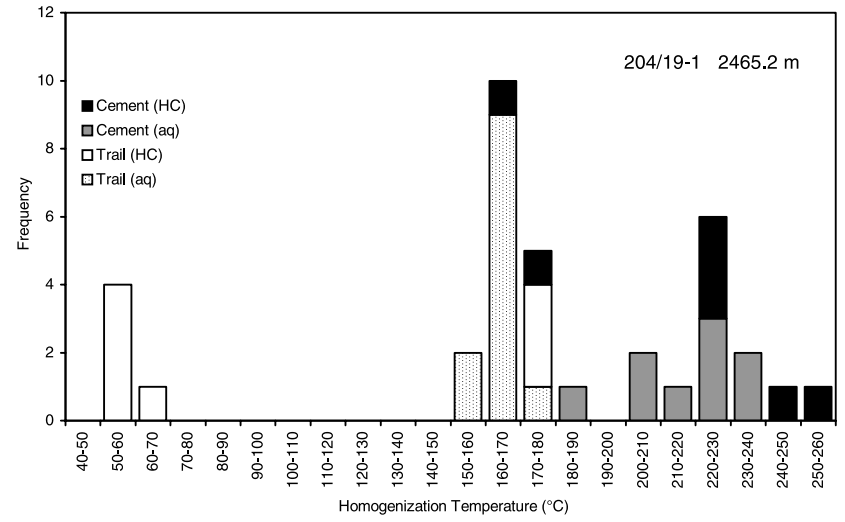

Fig. 8. Histogram of fluid inclusion temperatures for a sample from the Paleocene of well 204/19-1, depth $2684.7 \mathrm{~m}$. Note anomalously high temperatures for both aqueous and oil inclusions.

$41^{\circ}$ to $45^{\circ} \mathrm{API}$, whereas the predominant population of inclusions in the Paleocene samples is of a heavy, viscous oil (API not determinable, but heavier than $20^{\circ}$ ).

Since apatite fission track analysis and vitrinite reflectance data rule out an explanation of these high inclusion temperatures in terms of depth of burial, it is concluded that they represent the effect of hot fluids, circulating within the shallow part of the section, which is supported by the anomalous nature of these temperatures within the overall depth profile. The high temperatures recorded in the oil inclusions indicate that oil was involved fundamentally in the hot fluid story.

Data are also available for the Cretaceous and Cenozoic sections in well 214/29-1 (Wycherley et al. 2003), where anomalously high fluid inclusion temperatures were similarly encountered in the Cenozoic section but not in the Cretaceous section. In well 206/5-2, once again the highest fluid inclusion temperatures are recorded in the Cenozoic section (Wycherley et al. 2003) and, as in well 204/19-1, the high temperatures of the Cenozoic section are recorded in the oil inclusions, emphasizing a relationship between oil and hot fluid.

\section{Organic geochemistry}

The oil inclusions in the Cretaceous sandstones in well 204/ 19-1 are sufficiently abundant to yield a well-defined whole oil gas chromatogram (Fig. 9a). There is not such a high abundance in Paleocene samples from this well, so the chromatograms from them are less well defined (Fig. 10a) and of limited value. A chromatogram from Cenozoic-hosted oil inclusions in nearby well 204/24a-2 (depth $2138.5 \mathrm{~m}$ ) is better defined but also incomplete (Fig. 10b). For comparison, an oil sample from the pore space in a Paleocene sandstone in another nearby well (204/24-1, depth $2153.0 \mathrm{~m}$ ) is also shown (Fig. 9c).

The chromatogram obtained from Cretaceous-hosted inclusion oil is dominated by a suite of $n$-alkanes out to $n \mathrm{C}_{26}$, with a maximum at $n \mathrm{C}_{14}$. The limited chromatogram from the Cenozoic sample in 204/19-1 shows $n$-alkanes with a maximum at $n \mathrm{C}_{15}$. The chromatogram from the Cenozoic of $204 / 24 \mathrm{a}-2$ also shows $n$-alkanes with a maximum at $n \mathrm{C}_{15-16}$, but also identifiable isoprenoids $\left(\mathrm{IP}_{15-16}\right)$, and a 'hump' (unresolved complex mixture reflecting degradation). These features distinguish the Cenozoic-hosted inclusion oil from the Cretaceous-hosted inclusion oil. The pore oil sample shows a large 'hump', with a well-defined suite of $n$-alkanes out to $n \mathrm{C}_{36}$ superimposed. This appears to be a mixture of a degraded and a fresh oil, respresented by the complex mixture and the well-defined $n$-alkanes, respectively. Other published organic geochemical data for oils from the West of Shetland region also 


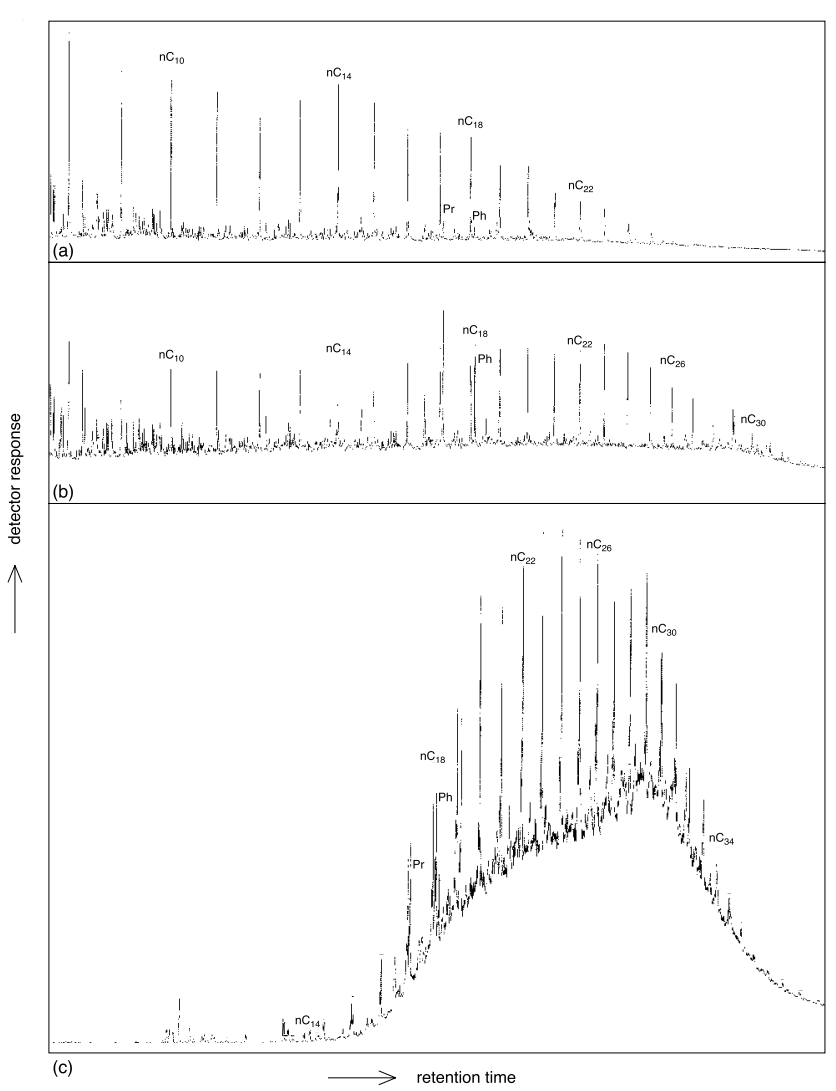

Fig. 9. Whole oil gas chromatograms: (a) inclusion oil, Cretaceous sandstone, well 204/19-1, depth $4210.2 \mathrm{~m}$; (b) inclusion oil, Jurassic sandstone, well 206/5-1, depth $3151.0 \mathrm{~m}$; (c) present-day pore oil, Paleocene sandstone, well 204/24-1, depth $2153.0 \mathrm{~m}$. (a) is dominated by low-end $n$-alkanes, typical of Kimmeridge-derived oil; (b) is much more waxy (heavier $n$-alkanes); (c) has a large hump (unresolved complex mixture) due to degradation, with well-defined $n$-alkanes superimposed which may represent addition of a fresher oil. Inclusion oils do not show degradation.

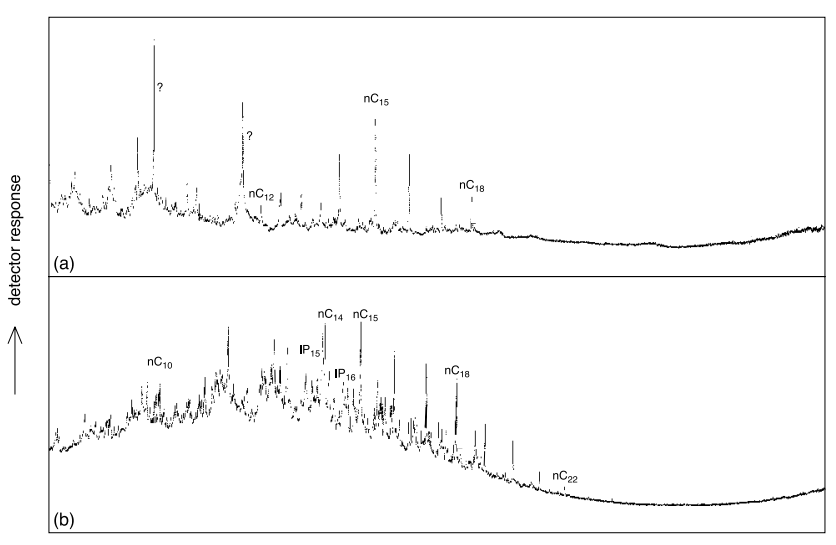

$\longrightarrow$ retention time

Fig. 10. Whole oil gas chromatograms of inclusion oils in Paleocene sandstones: (a) well 204/19-1, depth 2688.9 m; (b) well 204/24a-2, depth $2138.5 \mathrm{~m}$. (a) contains very spare oil inclusions, hence signal is very limited; (b) is also weak, but signal is adequate enough to show isoprenoid alkanes as well as $n$-alkanes, indicating probable degradation.

show evidence for mixture from two sources, believed to be Kimmeridgian (late Jurassic) and mid-Jurassic (Scotchman et al. 1998; Goodchild et al. 1999).

The contrast between inclusion oil chemistry and pore oil chemistry is highlighted by a cross-plot of $n \mathrm{C}_{27} / n \mathrm{C}_{17}$ (a measure of 'terrestriality', as $\mathrm{C}_{27}$ increases in more waxy, terrestrial, oils) against $\mathrm{IP} / n\left(\mathrm{C}_{14}-\mathrm{C}_{16}\right)$ (ratio of isoprenoids to $n$-alkanes over $\mathrm{C}_{14}$ to $\mathrm{C}_{16}$ range, which increases with biodegradation) (Fig. 11). The inclusion oil has a much lower terrestrial component, as it is probably derived from a marine Kimmeridgian source. The pore oil has a terrestrial component added to it. The pore oil is also more degraded, which must be partly a fossil process because the chromatogram shows a well-preserved heavy, waxy oil superimposed on the degraded component. There may have been further alteration during core storage, or a second less severe degradation event, reflected in the loss of light $n$-alkanes. For comparison, the figure shows that a comparable trend, from low-terrestriality inclusion oil to high-terrestriality/degraded pore oil, is exhibited by oil in the Clair Field, West of Shetland. The host rocks in the Clair Field are more wide-ranging, but aspects of the oil charge history may be comparable (Grant et al. 1999). In both cases the inclusion oil does not contain the waxy, terrestrial oil. Some inclusion oils in the West of Shetland region do show the presence of the waxy component, as exemplified by a sample from the Jurassic of 206/5-1 (Fig. 9b) which clearly had a different oil charge history to the rocks in 204/19-1. These observations emphasize the value of fluid inclusions in constraining charge histories.

\section{Host cements}

Quartz cement types may provide valuable information with regard to rates of silica cementation (Walderhaug 1994). Sandstone cements may form slowly in response to pressure solution, or rapidly by precipitation from cooling fluids. When crystallization is slow enough to permit the build up of chemical gradients at the crystal growth front, cements can record small-scale zonation (oscillatory zonation). Oscillatoryzoned cements are, therefore, characteristic of the closed system, episodic cementation associated with burial diagenesis. In contrast, the cooling of pore fluids and the resulting decrease in solubility may result in the precipitation of unzoned cements. Zoned and unzoned cement morphologies can be discriminated easily using scanning electron microscopy cathodoluminescence (SEM-CL). There is a marked distinction in SEM-CL characteristics between quartz cements from preCenozoic and Cenozoic sandstones in the West of Shetland region, recorded from a number of wells by Wycherley et al. (2003). This is also evident in samples from the Cretaceous and Paleocene of 204/19-1 (Fig. 12). Paleocene quartz overgrowths occur most frequently as multiple small euhedral unzoned prisms, while Cretaceous cements show mainly blocky or patchily zoned morphologies (although oscillatory zoned cements have been noted). The simplest interpretation for the restriction of unzoned cements to Paleocene samples is that they precipitated from the cooling of hot fluids as they migrated along aquifer horizons.

\section{SYNTHESIS OF FISSION TRACK AND VITRINITE REFLECTANCE DATA WITH FLUID INCLUSION DATA}

The fluid inclusion measurements presented in the previous section reveal consistent evidence of extremely hot fluids, at temperatures up to $200^{\circ} \mathrm{C}$ or above, which appear to delineate a marked thermal anomaly within the Paleocene sandstones in the 204/19-1 well (Fig. 7). These hot fluids appear to have had no detectable effect on either the fission track or vitrinite reflectance data in the well. The vitrinite reflectance data show a progressive increase down the well suggestive of heating related to burial, while the fission track data are dominated by 


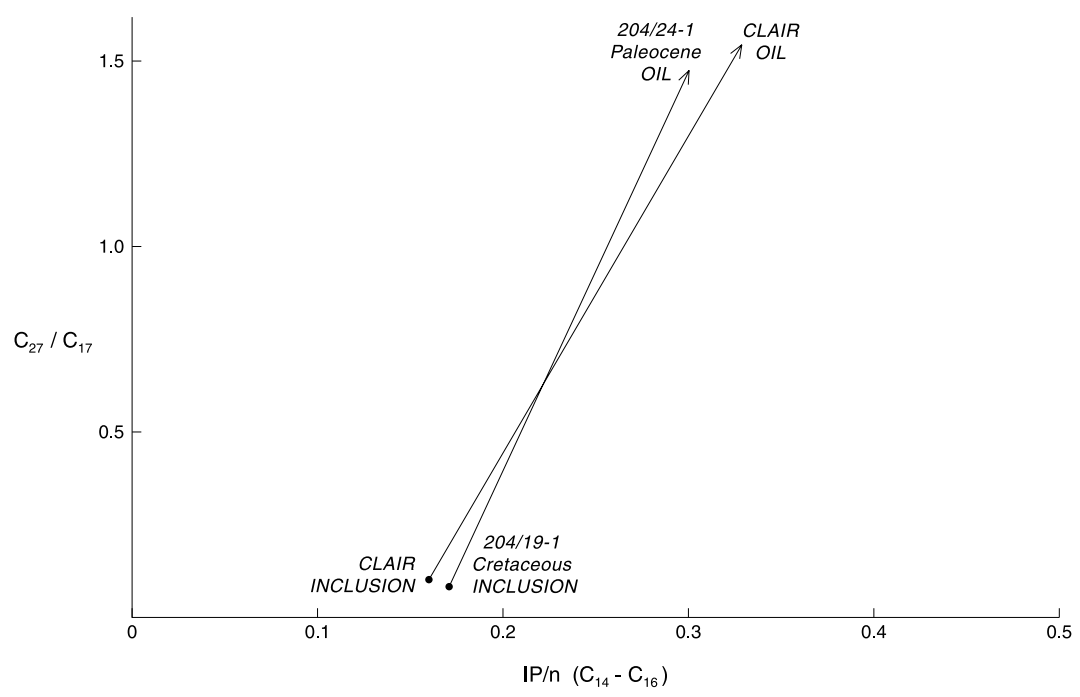

Fig. 11. Cross-plot of $n$-alkane $\mathrm{C}_{27} / \mathrm{C}_{17}$ ratio (increase with waxiness, 'terrestriality') against isoprenoid/ n-alkane ratio for $\mathrm{C}_{14}$ to $\mathrm{C}_{16}$ (increases with degradation). Comparison of chemistry of inclusion oil and present-day pore oil in Quad 204 and nearby Clair oil field shows that in both cases pore oil is more terrestrial and more degraded. Increased 'terrestriality' over time consistent with first charge of Kimmeridge-sourced oil followed by addition of a waxier oil. the effects of tracks formed prior to deposition, clearly ruling out any significant effect beyond that defined by the reflectance data.

(a)

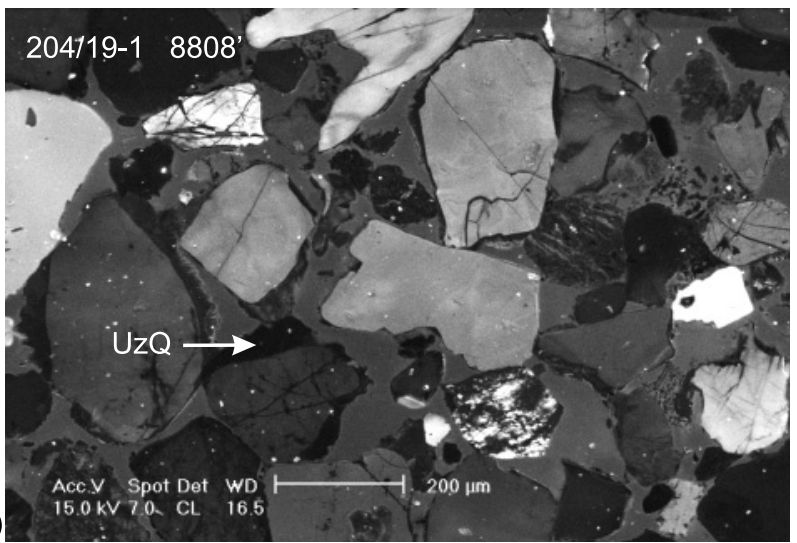

(b)

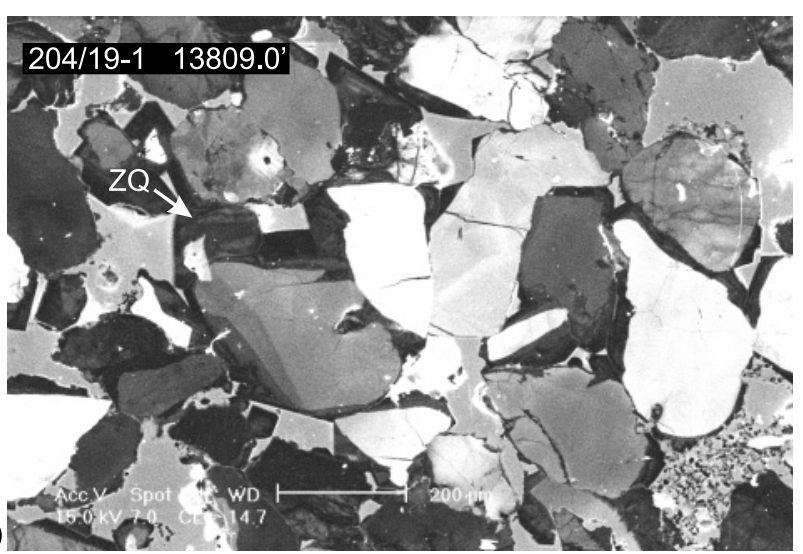

Fig. 12. Scanning electron microscope cathodo-luminescence (SEM-CL) images of quartz cements in two samples from well 204/19-1. (a) Unzoned quartz overgrowths (Paleocene, depth $2712.9 \mathrm{~m}$ ). Weakly luminescing overgrowths form narrow rims around the majority of grains. Where thicker overgrowths are developed (e.g. UzQ) the cements are characterized by homogeneous, non-luminescing material. Irregular overgrowth margins are evident on several grains. (b) Zoned quartz overgrowths ( $\mathrm{ZQ}$ ) (Cretaceous, depth $4209.0 \mathrm{~m}$ ). Overgrowths are wider (up to $100 \mu \mathrm{m})$, more regular in shape and show patchy and oscillatory zonation.
The lack of effect of heating to $200^{\circ} \mathrm{C}$ or more on the fission track or vitrinite reflectance data presumably reflects the fact that heating associated with the hot fluids was extremely rapid, such that the duration of heating was insufficient to produce a significant effect. Figure 13 shows an attempt to assess this more quantitatively, by modelling fission track and vitrinite reflectance data through various thermal history scenarios, varying the duration of heating and calculating the fission track and vitrinite reflectance parameters expected in each case. The Paleocene core at a depth of $2687 \mathrm{~m}$ (measured depth, md) is the basis for these calculations. This core shows fluid inclusion homogenization temperatures around $200^{\circ} \mathrm{C}$ (Fig. 8), so the effect on the fission track and vitrinite reflectance parameters of heating to this temperature has been calculated over various time intervals, superimposed on the default thermal history for this sample, as shown in Figure 13.

The calculated trend of fission track age (for apatites with between $0.0 \mathrm{wt} \% \mathrm{Cl}$ and $0.1 \mathrm{wt} \% \mathrm{Cl}$ ) vs. duration of heating (taken as the time between initiation of heating from the default thermal history and the attainment of maximum temperature) in Figure 13 shows that for durations greater than 100 years $\left(10^{-4} \mathrm{Ma}\right)$, severe to total fission track annealing is expected. Apatites in three closely spaced samples from this depth show clearly only minor length and age reduction (Table 1) and that the time spent at $200^{\circ} \mathrm{C}$ or above must be less than this limit. Vitrinite reflectance data lead to similar conclusions. Note that such reasoning takes the kinetic models of fission track annealing and vitrinite reflectance evolution beyond the time ranges in which they are normally applied and in which they are well calibrated and, therefore, the results should probably be accepted only semi-quantitatively.

Note also that these calculations ignore the effect of any fission tracks formed prior to deposition, but this does not affect the conclusions, as the conditions predicting total annealing will still produce total annealing, no matter how many tracks are present initially.

\section{CONDITIONS OF HOT FLUID FLOW}

As discussed earlier, the Cretaceous section was by-passed by the hot fluid pulse, which must have reached well 204/19-1 by up-dip movement through a Paleocene-Eocene aquifer, or along fractures, such as the fault plane identified in this well.

It is very unlikely that flow through the matrix permeability of a sandstone aquifer could preserve a significant thermal anomaly. A fluid at $200^{\circ} \mathrm{C}$ passing through a sandstone aquifer 

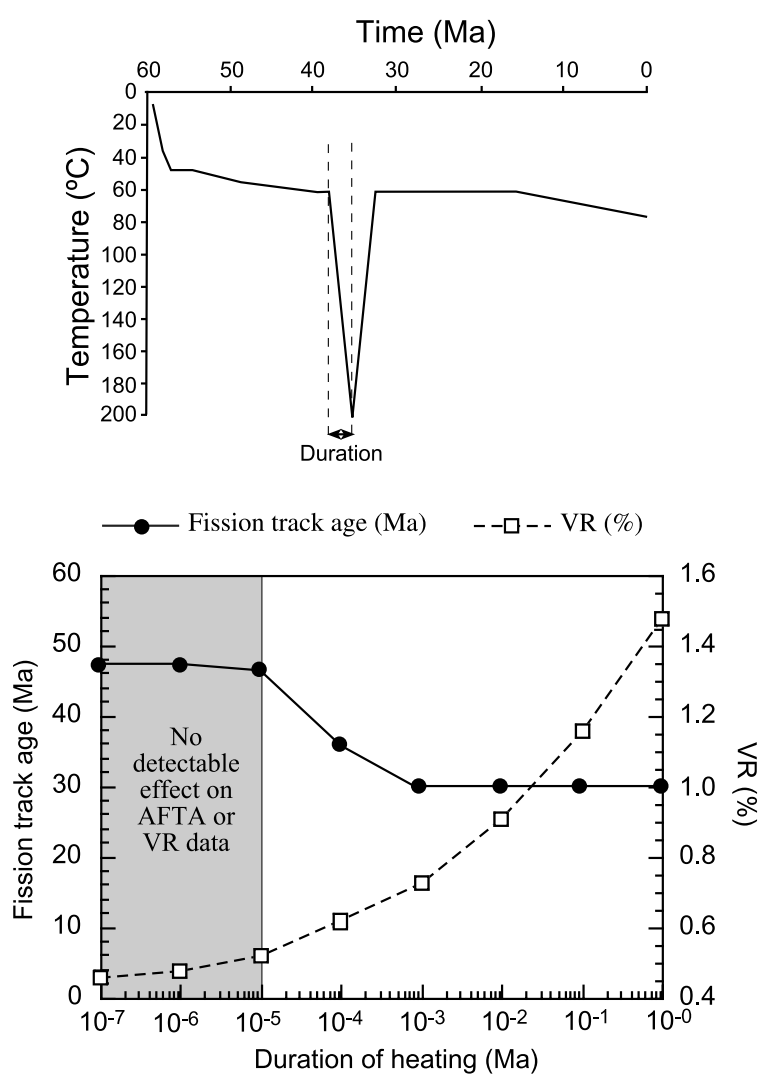

Fig. 13. Lower plot shows values of fission track age and vitrinite reflectance predicted from thermal histories, with the general form shown in the upper plot, for different values of the duration of heating (taken as the time period from the onset of heating to the attainment of the maximum temperature of $200^{\circ} \mathrm{C}$ ). This history is based on the default thermal history for the composite sample of Late Paleocene sandstone from a depth interval of $2685 \mathrm{~m}$ to $2690 \mathrm{~m}$ in the 204/19-1 well. Details of the calculations are described in the text. For short heating durations, fission track ages and vitrinite reflectance show little or no detectable effect but, as duration increases, the effect on the parameters is clear. The absence of any detectable local effects in this and adjacent samples, despite fluid inclusion homogenization temperatures of $c .200^{\circ} \mathrm{C}$ or higher, suggests that heating associated with the passage of the fluids from which the cements were precipitated was extremely rapid, and/or extremely local. Adjusting the timing of the thermal anomaly makes negligible difference to the calculations of heating time.

with an ambient temperature of $100^{\circ} \mathrm{C}$, at a relatively slow flow rate and a low fluid-rock surface area ratio would experience rapid dissipation of heat. This implies that flow was through fractures, in which the flow rate and fluid-rock surface area ratio would be higher, and the plumbing system would penetrate to high ambient rock temperatures more readily. Fracture systems have been deduced as an essential aspect of the fluid flow system in the region, necessary for hydrocarbon migration (Iliffe et al. 1999).

A fracture system would pass through the Cretaceous sandstone (Iliffe et al. 1999), so one would expect to see a hot fluid signature at that level unless the porosity in it was too low for fluids to penetrate much beyond the fractures. Petrographic data show that before quartz and calcite cementation, the Cretaceous sandstones had $15 \%$ to $25 \%$ porosity, but only about $5 \%$ after cementation. As the hot fluid signature is not seen in the cements of the Cretaceous sandstones, this implies that cementation occurred before the hot fluid event and that the oil entrapped in the cement pre-dates that event.
Supporting evidence comes from the SEM-CL observations of the quartz cements, which show that the cement in the Cretaceous sandstones is quite distinct from that in the Paleocene sandstones. As the cement zonation observed in the Cretaceous is not seen in the Paleocene section, the cements in the Cretaceous section were probably precipitated earlier. The unzoned cement in the Paleocene suggests rapid precipitation of the quartz in a single event, as expected from a cooling hot fluid. These inferences are consistent with cementation of the Cretaceous sandstones before the hot fluid event.

\section{TIMING OF OIL CHARGE}

The chemistry of the inclusion oil in well 204/19-1 Cretaceous sandstone suggests that it is probably a single-source oil. The simple pattern of $n$-alkanes with a maximum at $n \mathrm{C}_{14}$ is comparable with chromatograms derived from Kimmeridgian shale samples and Kimmeridgian-sourced oils (Scotchman et al. 1998). Given that this is the major source in the region, it is inferred that the Cretaceous-hosted inclusion oil was derived from the Kimmeridgian. As present-day oils in the region are a mixture from two sources, identified by Scotchman et al. (1998) as Kimmeridgian and mid-Jurassic, the observations indicate that the Kimmeridgian oil was the first of the two to migrate into the Cretaceous sandstones and elsewhere. Although the Kimmeridgian is the stratigraphically shallower of the two sources, it may have generated oil first for kinetic reasons or because the kitchen for the first oil charge is located where the mid-Jurassic source is missing. Holmes et al. (1999) report that the Kimmeridgian source organic matter was more reactive and is likely to have generated oil before the deeper source. Hence, the observations reported here are consistent with the predictions made from source-rock geochemistry.

The pore oil from well 204/24-1 shows a longer (heavier) suite of $n$-alkanes and an additional $n$-alkane maximum at $n \mathrm{C}_{29}$, which is consistent with the addition of a waxy component of oil such as would have been generated from the mid-Jurassic (Scotchman et al. 1998). Unfortunately, the Cenozoic-hosted inclusion oil chromatograms are inadequate to assess their character and sources fully. However, the high ratio of isoprenoids to $n$-alkanes at $\mathrm{C}_{15-16}$ and the 'hump' in Figure 10 indicates that the oil in the inclusions is degraded.

The Cretaceous-hosted inclusion oil has not experienced the hot fluid pulse directly, indicated by the lack of anomalously hot aqueous inclusions in the Cretaceous section. In fact, the Cretaceous sandstone had probably been cemented prior to the hot fluid event, as argued above. This not only sealed up the rock to further fluids, but isolated the oil as inclusions and prevented it from migration or alteration. The 'hot' oil in the Cenozoic section was, therefore, not simply remigrated from the immediately underlying Cretaceous section.

The Cretaceous-hosted inclusion oil appears to have predated the hot fluid event, but that constraint still allows a significant time period for entrapment within cement. The persistence of the hot fluid signature up to Eocene level shows that the event can be no older than Eocene (Wycherley et al. 2003). By that time, the Lower Cretaceous would have attained most of its current thermal maturity. As the fluid inclusion temperatures in the Cretaceous section appear to be in equilibrium with the reflectance-derived temperatures, the inclusions of aqueous fluid and oil were entrapped under conditions of near-maximum burial-temperature, shortly before the onset of Eocene-Miocene inversion. The hot fluid event then followed and could have been during or after the inversion. Tectonic activity related to inversion might actually have triggered the fluid flow event. 


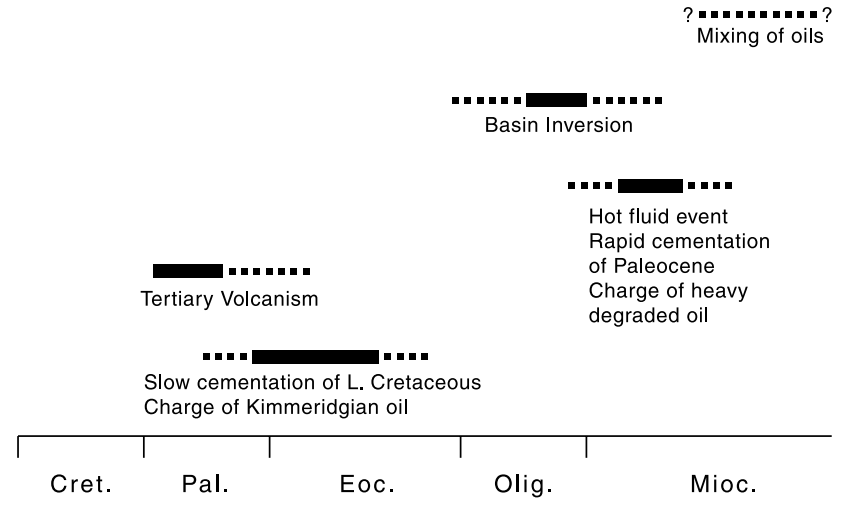

Fig. 14. Summary of heating and oil charge events deduced from integrated thermal and geochemical data (see text for details).

There is evidence from mineralogy, fission track data and thermal history modelling for anomalous heating during the Oligo-Miocene (Davies \& Cartwright 2002; Green et al. 2002; Carr \& Scotchman 2003), although not on such a pronounced scale. Increased, pulsed activity of the Iceland plume at this time (Lundin \& Doré 2001) may have been a driving force for hot fluid movement. The proposed model dates the hot fluids to a younger time than suggested by Wycherley et al. (2003) who assumed that the host Paleocene and Eocene rocks were cemented very early by hot fluids. However, cementation in sandstones commonly occurs millions to tens of millions of years after deposition, so a younger age is perfectly feasible and avoids the need to have a series of hot fluid events over a long time period to cement sandstones of both Paleocene and Eocene age, as suggested by Wycherley et al. (2003).

The timing of addition of the second, waxy, oil component is difficult to constrain. As the hot inclusions in the 204/19-1 well Cenozoic section include oil that was not tapped from the underlying Cretaceous, the hot fluid event introduced a new charge of oil. This could be when the second component seen in present-day oils was added, but at present this cannot be proved directly. However, it is known that the oil trapped in the Cenozoic section is a heavy oil that has probably been degraded. It is not simply oil with a waxy, terrestrial component, as the waxy inclusions of this origin in well 206/5-1 have an API of $27^{\circ}$ to $29^{\circ}$, that is quite distinct from the heavy viscous oil in inclusions in the Cenozoic sandstones of well 204/19-1. Thus, the hot fluid event involved migration of a heavy degraded oil. Degradation may have been a consequence of interaction with the flush of water during the event. However, biodegradation is unlikely at high temperatures, so either the oil was altered by a non-biological process (e.g. water washing) or it was biodegraded at lower temperatures and tapped by the migrating hot fluids.

In summary, the geochemical data suggest a pulse of oil derived from the Kimmeridgian before the hot fluid event, followed by introduction of degraded oil associated with the event. The timing of these charges relative to key Cenozoic events is summarized in Figure 14.

\section{Models}

The observations presented here are consistent with aspects of other models for oil migration in the West of Shetland region proposed on geochemical, thermal and pressure data. In particular, the inference of more than one stage of oil charge is consistent with mixing from more than one source (Scotchman et al. 1998); the inference of rapid flow through fracture systems is consistent with the overpressure-hydrofracturing envisaged by Iliffe et al. (1999) and Holmes et al. (1999); and the inference of thermal anomaly as a consequence of hot fluids is consistent with earlier deductions from fission track data by Green et al. (1999). However, this study has attempted to integrate these aspects. Hence, it is proposed that the hot fluids necessitate fracture-bound flow and that this included a stage of the oil charge history.

The data reported here do not constrain the origin of the hot fluid event, excepting the inference that it was short lived. The proximity to both intrusive and extrusive Cenozoic volcanism (Fig. 1) makes this a potential candidate, but the inferred post-Mid Eocene age for this event is younger than the dates obtained from igneous rocks (Ritchie et al. 1999). The conclusion that the hot fluid event post-dated the onset of Late Cenozoic inversion raises the possibility that the release of the fluids may have been triggered in some way by the inversion event. While this remains speculative at this stage and requires further scrutiny, it suggests that such effects may be widespread on continental margins where significant inversion has occurred. Data from elsewhere on the Atlantic margin indicate that hot fluid events have occurred at several times since the Carboniferous (Green et al. 1999; Parnell et al. 1999) and growing evidence from other parts of the world (e.g. Kennard et al. 1999; Xie et al. 2001) suggests that hot fluid pulses may be a normal feature of continental margin basins.

\section{CONCLUSIONS}

Integration of the apatite fission track, vitrinite reflectance and fluid inclusion data imposes important constraints on the thermal history of the rocks in well 204/19-1 and potentially on other parts of the European Atlantic margin.

1. Fission track and vitrinite reflectance data indicate that heating due to burial did not give rise to temperatures more than $20^{\circ} \mathrm{C}$ above present values. Up to $900 \mathrm{~m}$ of additional burial and exhumation is inferred.

2. Additional heating affected rocks of Middle Eocene age and older, indicating that heating and cooling began after deposition of the Middle Eocene. This is consistent with late Cenozoic (Eocene to Miocene) basin inversion (Fig. 14).

3. The fluid inclusion data indicate the passage of very hot fluids (up to $200^{\circ} \mathrm{C}+$ ) in Paleocene-Eocene rocks, which must have been of short duration to show no effect on the fission track and vitrinite reflectance data. Modelling suggests that the duration may have been less than 100 years.

In terms of the oil charge history, it is deduced that:

1. the first oil to charge the oil mixture found in Quad 204 originated from an Upper Jurassic (Kimmeridgian) source rock;

2. the Kimmeridgian-sourced oil, recorded in Cretaceoushosted cement, had charged the sequence before the hot fluid event;

3. the hot fluid event introduced a new charge of oil, which was biodegraded, recorded in Paleocene-hosted cement.

This study represents the first integrated treatment of fission track and fluid inclusion data for the Cretaceous-Cenozoic section on the UK Atlantic margin. It is evident that the previous record of hot fluids in the Jurassic section (Parnell et al. 1999) is applicable to the key reservoir section of Tertiary age, where the hot fluid pulse was probably focused. It has also been possible to incorporate earlier observations of oil inclusions (Parnell et al. 1998) into a model that constrains their timing and improves understanding of the charge history. 
The authors thank BP, Conoco (UK) and TotalFinaElf for access to samples and permission to publish data. Skilled technical assistance was provided by J. B. Fulton. This project was undertaken partly with support from grant GST/02/2868 from the Natural Environment Research Council. The authors are grateful to A. Carr, J. P. Rogers and G. Nadon for comments on an earlier draft. AFTA $^{\circledR}$ is a registered trademark of Geotrack International Pty Ltd.

\section{REFERENCES}

Andrews-Speed, C.P., Oxburgh, E.R. \& Cooper, B.A. 1984. Temperatures and depth-dependent heat flow in Western North Sea. AAPG Bulletin, 11, $1764-1784$.

Bray, R.J., Green, P.F. \& Duddy, I.R. 1992. Thermal history reconstruction using apatite fission track analysis and vitrinite reflectance: a case study from the UK East Midlands and the Southern North Sea. In: Hardman, R.F.P. (ed.) Exploration Britain: Into the next decade. Geological Society, London, Special Publications, 67, 3-25.

Burnham, A.K. \& Sweeney, J.J. 1989. A chemical kinetic model of vitrinite reflectance maturation. Geochimica et Cosmochimica Acta, 53, 2649-2657.

Carr, A. 2000. Suppression and retardation of vitrinite reflectance, Part 1. Formation and significance for hydrocarbon generation. Journal of Petroleum Geology, 23, 313-343.

Carr, A.D. \& Scotchman, I.C. 2003. Thermal history modeling in the southern Faroe-Shetland Basin. Petroleum Geoscience, 9, 333-345.

Cook, A.C. (ed.) 1982. The origin and petrology of organic matter in coals, oil shales and petroleum source rocks. University of Wollongong, Wollongong, New South Wales.

Crowhurst, P.V., Green, P.F. \& Kamp, P.J.J. 2002. Appraisal of (U-Th)/He apatite thermochronology as a thermal history tool for hydrocarbon exploration: an example from the Taranaki Basin, New Zealand. AAPG Bulletin, 86, 1801-1819.

Davies, R.J. \& Cartwright, J. 2002. A fossilized Opal A to Opal C/T transformation on the northeast Atlantic margin: support for a significantly elevated palaeogeothermal gradient during the Neogene? Basin Research, 14 467-486.

Duddy, I.R., Green, P.F., Bray, R.J. \& Hegarty, K.A. 1994. Recognition of the thermal effects of fluid flow in sedimentary basins. In: Parnell, J. (ed.) Geofluids: Origin, Migration and Evolution of Fluids in Sedimentary Basins. Geological Society, London, Special Publications, 78, 325-345.

Ebdon, C.C., Granger, P.J., Johnson, H.D. \& Evans, M.D. 1995. Early Tertiary evolution and sequence stratigraphy of the Faeroe-Shetland Basin: Implications for hydrocarbon prospectivity. In: Scruton, R.A., Stoker, M.S., Shimmield, G.B. \& Tudhope, A.W. (eds) The Tectonics, Sedimentation and Palaeoceanography of the North Atlantic Region. Geological Society, London, Special Publications, 90, 51-69.

Galbraith, R.F. \& Laslett, G.M. 1993. Statistical methods for mixed fission track ages. Nuclear Tracks, 21, 459-470.

Goodchild, M.W., Henry, K.L., Hinkley, R.J. \& Imbus, S.W. 1999. The Victory gas field, West of Shetland. In: Fleet, A.J. \& Boldy, S.A.R. (eds) Petroleum Geology of Northwest Europe: Proceedings of the 5th Conference. Geological Society, London, 713-724.

Grant, N., Bouma, A. \& McIntyre, A. 1999. The Turonian play in the Faeroe-Shetland Basin. In: Fleet, A.J. \& Boldy, S.A.R. (eds) Petroleum Geology of Northwest Europe: Proceedings of the 5 th Conference. Geological Society, London, 661-673.

Green, P.F. 1981. A new look in statistics in fission-track dating. Nuclear Tracks, 5, 77-86.

Green, P.F. 1986. On the thermo-tectonic evolution of Northern England: evidence from fission track analysis. Geological Magazine, 123, 493-506.

Green, P.F., Duddy, I.R., Laslett, G.M., Hegarty, K.A., Gleadow, A.J.W. \& Lovering, J.F. 1989. Thermal annealing of fission tracks in apatite 4. Quantitative modelling techniques and extension to geological timescales. Chemical Geology (Isotope Geoscience Section), 79, 155-182.

Green, P.F., Duddy, I.R. \& Bray, R.J. 1995. Applications of Thermal History Reconstruction in inverted basins. In: Buchanan, J.G. \& Buchanan, P.G. (eds) Basin Inversion. Geological Society, London, Special Publications, 88, 149-165.

Green, P.F., Duddy, I.R., Hegarty, K.A. \& Bray, R.J. 1999. Early Tertiary heat flow along the UK Atlantic margin and adjacent areas. In: Fleet, A.J. \&
Boldy, S.A.R. (eds) Petroleum Geology of North West Europe, Proceedings of the 5th Conference. Geological Society, London, 348-357.

Green, P.F., Duddy, I.R. \& Hegarty, K.A. 2002. Quantifying exhumation in sedimentary basins of the UK from apatite fission track analysis and vitrinite reflectance data: precision, accuracy and latest results. In: Doré, A.G., Cartwright, J.A., Stoker, M.S., Turner, J.P. \& White, N.J. (eds) Exhumation of the Circum-Atlantic Margins. Geological Society, London, Special Publications, 196, 331-354.

Green, P.F., Crowhurst, P.V. \& Duddy, I.R. 2004. Integration of AFTA and (U-Th)/He thermochronology to enhance the resolution and precision of thermal history reconstruction in the Angelsea-1 wellOtway Basin, SE Australia. PESA Eastern Australasian Basins Symposium II Proceedings (Adelaide, September). Petroleum Exploration Society of Australia, Adelaide, 117-131.

Harland, W.B., Armstrong, R.L. Cox, A.V. Craig, L.E., Smith, A.G. \& Smith, D.G. 1990. A Geologic Time Scale. Cambridge University Press, Cambridge.

Holmes, A.J., Griffith, C.E. \& Scotchman, I.C. 1999. The Jurassic petroleum system of the West of Britain Atlantic margin - an integration of tectonics, geochemistry and basin modelling. In: Fleet, A.J. \& Boldy, S.A.R. (eds) Petroleum Geology of Northwest Europe: Proceedings of the 5th Conference. Geological Society, London, 1351-1365.

Iliffe, J.E., Robertson, A.G., Ward, G.H.F., Wynn, C., Pead, S.D.M. \& Cameron, N. 1999. The importance of fluid pressures and migration to the hydrocarbon prospectivity of the Faeroe-Shetland White Zone. In: Fleet, A.J. \& Boldy, S.A.R. (eds) Petroleum Geology of Northwest Europe: Proceedings of the 5th Conference, 601-611.

Jowitt, R., Hindle, A., Jones, D. \& Rose, P. 1999. Petroleum systems analysis of the Paleocene play in the West of Shetland area. In: Fleet, A.J. \& Boldy, S.A.R. (eds) Petroleum Geology of Northwest Europe: Proceedings of the 5th Conference, 1367-1382.

Kennard, J.M., Deighton, I., Edwards, D.S., Colwell, J.B., O’Brien, G.W. \& Boreham, C.J. 1999. Thermal history modelling and transient heat pulses: New insights into hydrocarbon expulsion and 'hot flushes' in the Vulcan sub-basin, Timor Sea. APPEA Journal, 39, 177-207.

Lamers, E. \& Carmichael, S.M.M. 1999. The Paleocene deepwater sandstone play West of Shetland. In: Fleet, A.J. \& Boldy, S.A.R. (eds) Petroleum Geolog) of Northwest Europe: Proceedings of the 5th Conference, 645-659.

Lundin, E. \& Doré, A.G. 2001. Mid-Cenozoic post-breakup deformation in the 'passive' margins bordering the Norwegian-Greenland Sea. Marine and Petroleum Geology, 19, 79-93.

Parnell, J., Carey, P. \& Duncan, W. 1998. History of hydrocarbon charge on the Atlantic margin: Evidence from fluid-inclusion studies, West of Shetland. Geology, 26, 807-810.

Parnell, J., Carey, P.F., Green, P. \& Duncan, W. 1999. Hydrocarbon migration history, West of Shetland: integrated fluid inclusion and fission track studies. In: Fleet, A.J. \& Boldy, S.A.R. (eds) Petroleum Geology of Northwest Europe: Proceedings of the 5th Conference, 613-625.

Pratt, L.M. \& Burruss, R.C. 1988. Evidence for petroleum generation and maturation in the Hartford and Newark Basins. Bulletin U.S. Geological Survey, 1776, 74-79.

Ritchie, J.D., Gatliff, R.W. \& Richards, P.C. 1999. Early Tertiary magmatism in the offshore NW UK margin and surrounds. In: Fleet, A.J. \& Boldy S.A.R. (eds) Petroleum Geology of Northwest Europe: Proceedings of the 5th Conference, 573-584.

Scotchman, I.C., Griffith, C.E., Holmes, A.J. \& Jones, D.M. 1998. The Jurassic petroleum system north and west of Britain: a geochemical oil-source correlation study. Organic Geochemistry, 29, 671-700.

Shepherd, T., Rankin, A.H. \& Alderton, D.H.M. 1985. A Practical Guide to Fluid Inclusion Studies. Blackie, Glasgow.

Thomson, K., Underhill, J.R., Green, P.F., Bray, R.J. \& Gibson, H.J. 1999. Evidence from apatite fission track analysis for the post-Devonian burial and exhumation history of the Northern Highlands, Scotland. Marine and Petroleum Geology, 16, 27-39.

Walderhaug, O. 1994. Temperatures of quartz cementation in Jurassic sandstones from the Norwegian continental shelf-evident from fluid inclusions. Journal of Sedimentary Research, A64, 311-323.

Wycherley, H.L., Parnell, J., Watt, G.R., Chen, H. \& Boyce, A.J. 2003. Indicators of hot fluid migration in sedimentary basins: evidence from the UK Atlantic Margin. Petroleum Geoscience, 9, 357-374.

Xie, X., Li, S., Dong, W. \& Hu, Z. 2001. Evidence for episodic expulsion of hot fluids along faults near diapiric structures of the Yinggehai Basin, South China Sea. Marine and Petroleum Geology, 18, 715-728. 